\title{
AFRICAN TOURISM IN UNCERTAIN TIMES: COVID-19 RESEARCH PROGRESS
}

\author{
Christian M. ROGERSON \\ University of Johannesburg, School of Tourism \& Hospitality, College of Business \\ and Economics, Bunting Road, Johannesburg, South Africa, e-mail: chrismr@uj.ac.za \\ Jayne M. ROGERSON* \\ University of Johannesburg, School of Tourism \& Hospitality, College of Business \\ and Economics, Bunting Road, Johannesburg, South Africa, e-mail: jayner@uj.ac.za
}

\begin{abstract}
Citation: Rogerson C.M., \& Rogerson, M. (2021). AFRICAN TOURISM IN UNCERTAIN TIMES: COVID-19 RESEARCH PROGRESS. GeoJournal of Tourism and Geosites, 38(4), 1026-1032. https://doi.org/10.30892/gtg.38406-740
\end{abstract}

\begin{abstract}
COVID-19 is a trigger event which is changing the complexion of African tourism and the directions of African tourism research. This article offers an overview and commentary on the state of African research produced during the uncertain times of 2020-2021 in specific response to the immediate impacts and changes which have been catalysed by the pandemic. The article is a progress report to capture and profile the body of focussed contributions on COVID-19 and tourism which have appeared for sub-Saharan Africa. Further, it is a contribution towards strengthening our understanding of tourism and change in the Global South. Overall, the discussion serves to highlight an emerging African scholarship which is engaged on a range of issues around three core themes of ramification, adaptation and transformation.
\end{abstract}

Key words: COVID-19, tourism in change, Africa, ramification, adaptation, transformation, Global South

$* \quad * \quad * \quad * \quad * \quad *$

\section{INTRODUCTION}

The years 2020-2021 will be defined always by the enormous challenges and changes that COVID-19 has brought to everyday life. With continued travel and lockdown restrictions around COVID-19 severely impacting international tourism flows it is observed "in no uncertain terms, the pandemic has forever changed the tourism industry as we once knew it" (Sin et al., 2021: 655-656). Nevertheless, it must be acknowledged also that "change is a constant feature of tourism" (Saarinen and Rogerson, 2021: 4). Nair and Sinha (2020: 307) pinpoint that travel behaviours and specific changes in decision-making are "not new concepts in the tourism industry and have been especially important over the past two decades, as the industry has witnessed a range of catastrophes from natural disasters to terrorist attacks". Yet the COVID19 is distinctive for the truly global nature of the crisis as the pandemic effectively has halted the operations of the tourism sector in an unparalleled fashion as well as reshaping patterns of consumer travel demand and of supply chains (Buckley, 2020; Hall et al., 2020; Nair and Sinha, 2020; Cooper and Buckley, 2021; Nhamo et al., 2020; Gössling et al., 2021; Matiza and Slabbert, 2021; Pham et al., 2021; Rogerson and Rogerson, 2021a; Sharma et al., 2021; Tellioglu, 2021).

This article builds upon the foundations of such works with the modest goal of offering an overview and commentary on the state of African research produced during the uncertain times of 2020-2021 and in specific response to the immediate impacts and changes which have been catalysed by the pandemic. Methodologically, the paper undertakes a systematic literature review which follows procedures adopted in similar studies (eg. Alhammad, 2020; Chen et al., 2021; Trip et al., 2021). The analysis is informed by the viewpoint that "a review of past research efforts is an important endeavour in all academic research areas" (Nunkoo et al., 2013: 5). Among several advantages of undertaking review articles is the identification of research trends as well as potential knowledge gaps where additional research might be useful.

\section{UNCERTAIN TIMES}

Arguably, the pandemic is unlike many other disasters and crises that previously have impacted the tourism sector and its enterprises (Hall et al., 2020). Bianchi (2020: 80) observes that "in contrast to previous disruptions, whether brought about by terrorism, natural disasters, financial crises or indeed previous pandemics, the outbreak of the COVID-19 pandemic has precipitated an unprecedented shutdown of travel and tourist destinations on a truly global scale". Seemingly, there will no return to the 'normal' as existed before (Brouder, 2020; Sigala, 2020; Butler et al., 2021; Gössling et al., 2021). Activities involving direct contact between consumers and service providers have been those most adversely impacted by restrictions imposed on movement and social distancing. The pandemic strikes at the very DNA of hospitality as social distancing is the absolute antithesis of what one traditionally expects from hospitality enterprises (Garrido-Moreno et al., 2021). The essence of hospitality is to create unique experiences which often are based on closeness with customers and personalized interactions. A redefinition of hospitality operations is taking shape (Pillai et al., 2021). Implementation of strategies to flatten the COVID19 curve such as lockdowns, stay-at-home orders, social distancing or mobility restrictions have resulted in the temporary

\footnotetext{
* Corresponding author
} 
(and increasingly permanent) closure of many tourism and hospitality establishments (Gursoy and Chi, 2020; Nhamo et al., 2020). For tourism enterprises Assaf and Scuderi (2020: 731) observe that COVID-19 "has been one of the most impactful and tragic pandemics of modern times". In the opinion of Duarte Alonso et al. (2020:1) the pandemic "represents the ultimate test for numerous leaders, entrepreneurs and employees operating in most if not all industries".

COVID-19 has generated an avalanche of writings from the community of international tourism and management scholars about its impact on the tourism and hospitality sectors. In addition, the pandemic is triggering changes in research agendas and shifts in the topics of tourism research (Brouder, 2020; Kock et al., 2020; Rogerson and Baum, 2020; Zenker and Kock, 2020; Assaf et al., 2021; Mattei et al., 2021; Persson-Fischer and Liu, 2021). For tourism scholars COVID-19 represents a critical challenge as "research that contributes to industry practice will need to reorient the focus of studies, given that the industry will undoubtedly change with new normal practices in place" (Kwok and Koh, 2021: 386). A thematic content analysis conducted of COVID-19 specific literature on tourism disclosed a number of critical themes that are emergent as well as new areas that merit further attention. Three thematic clusters of work were distilled in the content analysis recently performed by Kwok and Koh (2021). The first relates to 'ramification' which involves empirical assessments of the pandemic's impact on tourism, including changes in tourism demand as well as evaluations of the impacts of government support. The second concerns 'adaptation' which is a stream of investigations including responses in terms of the application of new technologies as well as explorations of the capacity of destinations and tourism businesses to adapt to change and build resilience. The third is 'transformation' which relates to the major corpus of work which is forwardlooking to the extent that it is analysing the prospects for restructuring future tourism and offering post-pandemic outlook analysis (Bianchi, 2020; Brouder, 2020; Butler, 2020; Higgins-Desbiolles, 2020a, 2020b; Niewiadomski, 2020).

Reviewing international tourism research controversies about COVID-19 Saarinen and Wall-Reinius (2021) identify the appearance and consolidation of two differing narratives or schools of thought on 'transformation'. Both narratives highlight the seriousness of the COVID-19 pandemic for global tourism, albeit differ in terms of what comes or should come next. First, is a 'resilience school of thought' which stresses the historical capacity of the tourism sector to cope with or adapt to shocks such as the global financial crisis, SARS, or natural events such as earthquakes or tsunamis (Saarinen and Wall-Reinius, 2021: 145). Much attention is upon the sector's capacity to return to pre-crisis growth paths. This perspective is projected by much of the tourism industry and would be the stance taken by national governments across sub-Saharan Africa. Second, is the 'readjustment school of thought' which emphasizes the imperative to re-think the 'growth at all cost' and 'volume at all cost' pathway for tourism which has dominated in recent years and partly is responsible for the current crisis (Saarinen and Wall-Reinius, 2021: 146).

For this second school COVID-19 is a watershed or turning point for tourism. It projects the changes and impacts as irreversible and fundamentally shifting the character of tourism and human mobility into the future (Higgins-Desbiolles, 2020b; Niewiadomski, 2020; Sigala, 2020). Put simply, it is argued that it is time to "question the sustainability of success defined by growth in visitor numbers or increases in material consumption" (Hall et al., 2020: 591). Pre-COVID-19 "many international organisations and policymakers framed the tourism industry and its local and regional development connections as high-potential tools for putting sustainable development into practice" (Saarinen, 2021: 15). HigginsDesboilles (2020a: 70) projects COVID-19 as a possible game-changer for global tourism and that it offers "a chance to turn away from the hegemony asserted by market forces for their profit and return to an earlier vision of tourism as a social force". Many academics contend that as COVID-19 exacerbates social and economic inequalities there is a need for recovery strategies which identify locally-tailored solutions to redefine tourism based on local rights, interests and benefits (Rastegar et al., 2021). Kwok and Koh (2021: 390) aver that "it is critical for tourism as a complex adaptive system to continue to respond, adjust and adapt with resiliency against COVID-19". The above context of international research debates around COVID-19 provides the setting for this discussion of African tourism research in uncertain times. Traditionally Africa has been on the periphery of mainstream international tourism scholarship and research debates (Rogerson, 2012; Adu-Ampong and Mensah, 2021). During the past decade, however, the volume of research generated on tourism in Africa has elevated noticeably (Senbeto et al., 2021). This surge is manifest most strikingly in the appearance of several valuable edited collections of new research about African tourism (Rogerson and Visser, 2020; Adu-Ampong and Kimbu, 2021; Leonard et al., 2021; Novelli et al., 2021; Ngoasong et al., 2021; Rogerson and Rogerson, 2021b).

\section{AFRICAN TOURISM RESEARCH RESPONSES TO COVID-19}

During the onset of the pandemic it was often stated that Africa had escaped the worst of COVID-19; by mid-2021 there was little sign of the continent being spared, most especially with the impact of the third wave. The spatial spread of the pandemic, its impacts for the African continent's health care system, socio-economic ramifications and government policy responses have been well-documented (eg. Acquaah et al., 2021; OECD, 2020; Ozili, 2020). It is a familiar story of the implementation of drastic measures to combat public health effects, partial or complete lockdowns, and the closure of borders. Such developments have adversely affected national, regional and local economies, disrupted value chains, decreased consumer demand and intra- and inter-regional trade (Arezki et al., 2021a). The societal and business haemorrhage induced by COVID-19 as well as the hopelessness experienced by many African governments is typified by the recorded Zimbabwe experience (Chirisa et al., 2021). The businesses hardest hit by the pandemic are the continent's cohort of small, medium and micro-enterprises and informal businesses (Acquaah et al., 2021). Arguably, across Africa the danger is that the long-term ramifications of COVID-19 will be to reverse development gains made over previous decades and deepen the continent's chronic challenge of poverty (Buheji et al., 2020). COVID-19 is a trigger event which is changing African tourism and the directions of African tourism research. The crisis is exerting significant negative ramifications for African tourism as is 
disclosed by the OECD (2020). Using UNWTO data Nyaruwata and Mbasera (2021) indicate that Africa recorded a 74 percent decline in international tourism in 2020 as compared to 2019 with this negative trend accelerating in 2021. The UNDP (2021: 4) states that in 2021 whilst some countries have started reopening borders "the situation remains dire as waves of the pandemic continue to rage through the African continent". As tourism is highly demand elastic the trajectory of significant decline is confirmed most recently by the mining of 'big data' by Arezki et al. (2021b). Further ramification research has been pursued on the impact of the pandemic for the tourism industry as a whole of individual countries. This has been produced variously for Kenya (Muragu et al., 2021), South Africa (Rogerson and Rogerson, 2020a; Dube, 2021a; Sao Joao, 2021) and Tanzania (Mwamwaja and Mlozi, 2020). All these studies point to the atrophy experienced by African tourism.

The implications of the pandemic for the tourism industry of the Southern African Development Community (SADC) as a whole are assessed as setting back "the gains the region had accumulated over the twenty three years of working together" (Nyaruwata and Mbasera, 2021: 10). Gender disparities in tourism employment impacts are pinpointed for the case of South Africa (Chipumuro et al., 2021). Another thread of research centres on the uneven spatial impacts of the pandemic with its most devastating ramifications experienced in tourism-dependent destinations (Rogerson and Rogerson, 2020b, 2021c, 2021d). At Victoria Falls, Zimbabwe Sibanda and Cheer (2021) highlight that COVID-19 underscores the imperative for livelihood diversification in order to ensure that the town develops resilience to shocks that impact tourism visitation. Drummond (2021) reflects on the potential challenges and possible opportunities of COVID-19 for small towns. Issues surrounding government policy response, or the lack thereof, to the pandemic also have been explored in the African environment (Mensah and Boakye, 2021; Nyawo, 2020; Rogerson and Rogerson, 2020a). With limited financial resources to support businesses directly, for tourism recovery the logical and most widespread government response is promoting domestic tourism (Rogerson and Baum, 2020; Woyo, 2021). Arguably, the pandemic has fostered a heightened level of awareness of how important tourism experiences and consumption are for people and local communities (Saarinen and Wall-Reinius, 2021). The implications of the pandemic for specific sectors of the African tourism product mix further have been under scrutiny (Swart and Maralack, 2020; Adinolfi et al., 2021; Bama and Nyakana, 2021; Dube-Xaba, 2021; Mohamed, 2021; Sucheran, 2021; Woyo and Nyamandi, 2021). The implications of COVID-19 for 'distressed destinations' have been probed in the setting of Zimbabwe (Woyo, 2021). One distinctive African contribution for international scholarship is exploration of the impacts of COVID-19 for the economy of international informal sector business tourism (Makoni and Tichaawa, 2021). Of greatest importance is, perhaps, the pandemic's impacts for leisure-related nature tourism and of protected area management in Africa. Lewis et al. (2021) interrogate the potential for incentivising investment in natural capital protection environmental management in South Africa through pro-poor tourism. Across the continent the COVID-19 pandemic has confirmed both "how dependent some conservation areas and many local communities are on tourism, and also the physical and mental health benefits of nature for visitors" (Spenceley et al., 2021: 113).

The debilitating impact of the pandemic on wildlife tourism and for the livelihoods of communities involved in natural resource-based management programmes in Southern Africa has been clearly demonstrated (Nyaruwata and Mbasera, 2021). In the case of Botswana Hambira et al. (2021: 1) go so far as to characterise COVID-19 not only as a health challenge "but also a socio-economic and ecological emergency". The unsustainable and predominant dependence of the country's tourism sector especially nature-based tourism - on the international market has brought the industry to a standstill with devastating impacts upon local community development accompanying abrupt losses of income and employment (Stone et al., 2021).

A second stream of African tourism research associated with COVID-19 relates to the broad theme of adaption responses concerning the application of new technologies as well as explorations of the capacity of destinations and tourism businesses to adapt to change and build resilience. The role of new technologies and digital transformation are highlighted in a number of African studies (Arezki et al., 2021b; Masaki et al., 2021; Musango and Rusibana, 2021). The potential for virtual tourism in Africa as a means to contribute to sustainability under the impact of the pandemic has been explored in the distressed destination of Zimbabwe (Chirisa et al., 2020). Tourist business adaptation responses to COVID19 are highlighted through research investigations conducted both in Ghana and South Africa. Adaptive resilience emerges as a vital strategic response by small and medium enterprises to the COVID-19 pandemic (Aidoo et al., 2021). For tourism and hospitality businesses in Africa one of the first studies of crisis-coping strategies as well as immediate recovery strategies is research conducted in Ghana (Dayour et al., 2020). The Ghana investigation explored how tourism and hospitality small enterprises are managing the crisis given what they describe as their typical peculiarities of lack of adequate resources, use of informal risk management strategies and heavy reliance on social capital (Dayour et al., 2020). Crisis management responses involved different approaches; in many cases business operators used more than one coping mechanism and adaptation to the pandemic (Dayour et al., 2020). These included inter alia, cost reduction measures through lay-offs and non-payment of remunerations, rigorous social media marketing, application for government support, and diversifying their services to activities more resilient to the pandemic's impact. In the case of ecotourism in Ghana Soliku et al. (2021) point out that existing facilities are over-reliant on the international market and starting to pivot towards the promotion of domestic tourism. Certain parallels emerge with the results from South African research on the adaptive responses of local tourism businesses (Giddy and Rogerson, 2021; Rogerson, 2021; Rogerson et al., 2021).

For South Africa it is demonstrated that adaptation to the crisis has been challenging because of the financial distress experienced by tourism enterprises in the wake of minimal government support (Booyens et al., 2021). Adaptive responses included downsizing of businesses, including worker retrenchments, price-cutting and readjustments to attract the domestic market, limited initiatives towards product diversification, energetic social media marketing and, in the case of accommodation enterprises, the re-purposing of properties (Rogerson, 2021). A strengthening of local inter-enterprise cooperation has been an additional widespread response (Giddy and Rogerson, 2021; Rogerson, 2021). For nature-tourism 
enterprises alongside price discounts targeted at domestic tourists, the promotion of adjusted tourism product offerings towards an emerging Black South African middle class domestic market has been a favoured adaptive response (Giddy and Rogerson, 2021). Another dimension of policy adaptation to COVID-19 change is a revitalised focus on niche tourism for African tourism researchers. Several tourism scholars suggest that in a post-COVID-19 environment tourism is likely to see mobility patterns which are marked by a shift away from large group travel to a preference for smaller groups where the risk of catching an infection is reduced (Chebli and Said, 2020). Indeed, as an outcome of the risk perceptions surrounding COVID-19 the tourism sector is projected to see an expansion in various forms of special interest or 'niche travel' which will be driven primarily by the confidence of travelling in smaller groups and less risk-prone environments (Nair and Mohanty, 2021). COVID-19 introduces the opportunity to investigate tourism offerings in which smaller-scale, controlled and operated niche products can be established to satisfy the changing demands and needs of consumers. In the postCOVID-19 era the competitiveness and growth of African destinations must hinge, at least in part, upon their capacity to understand and adapt to the new equilibrium at which tourism may reach (Assaf et al., 2021).

Although the shape of that new equilibrium remains uncertain one certainty is that niche tourism development must be highly relevant for the future tourism development in sub-Saharan Africa. Among others, the UNDP (2021) advocates the identification of niche sectors to unlock competitiveness and maximise the potential of African tourism. For South Africa Rogerson and Rogerson (2021e) provide an overview analysis of current research debates on niche tourism and policy development. Of particular significance is the findings about the expanded importance of the niches of heritage tourism, gastronomy and creative tourism as well as planning for themed niche tourism route offerings.

In terms of transformation of tourism and future change the UNDP (2021) views the pandemic as an opportunity for revisiting the old business models of tourism in Africa. According to Ayiine-Etigo and Amankwah-Amoah (2021: 2) Africa's aviation sector potentially can be rebooted towards increasing intra-African travel and using African low-cost carriers which "have the transformative potential of sustainable tourism in Africa post-COVID-19". Looking forwards the UNDP (2021) urges a reshaping of African tourism as an anchor for endogenous and sustainable socio-economic growth. Rogerson and Baum (2020) argue that the COVID-19 crisis makes it imperative for African tourism research to become more aligned with the United Nations Sustainable Development Goals. Saarinen (2021: 25) opines that "tourism destination development should be managed for change, and there is a clear need for better destination governance towards SDGs, given the lesson the current crisis has provided us - not to mention the state of relatively near future affairs characterised by increasing globalisation, related economic insecurity and global climate change". In one recent African investigation Dube (2021b) reveals how the tourism industry of both Botswana and Zimbabwe is, to some extent, 'localising' the SDGs. It is demonstrated, however, that there is still a long way to go to ensure SDG localisation and considers "unlikely the sector will realise its full potential because of the lag taken to venture into the SDG space and the disruption caused by the COVID-19 pandemic" (Dube, 2021b: 12). Of particular concern for African tourism is the minimal attention which is devoted to SDG 13 on climate change, which will be the trigger for the forthcoming crisis that threatens to devastate the continent's tourism economy (Fitchett, 2021; Pandy and Rogerson, 2021; Saarinen, 2021). Finally, in terms of the theme of transformation and COVID-19, it has been argued that there is considerable value for African scholars to learn lessons from past experience and undertake historical tourism research studies which might resonate with contemporary debates. An instructive example is an investigation into South Africa's early development of health tourism which was linked to the perceived therapeutic impacts of the country's climate for $19^{\text {th }}$ century sufferers of tuberculosis (Rogerson and Rogerson, 2021f). The arrival of consumptive invalids from Europe seeking to benefit from climate therapy in South Africa was a vector for spreading tuberculosis during the early 20th century in a manner which parallels the 2020 origins of the COVID-19 pandemic in the country.

\section{CONCLUSION}

This article is a progress report which seeks to capture and profile the body of focussed contributions on COVID-19 and tourism which have appeared for sub-Saharan Africa, the least well-documented global region by tourism scholars. In addition, it represents a further contribution towards a strengthened understanding of tourism and change in the global South (Rogerson and Saarinen, 2021; Saarinen, 2021). Although certain other changes might emerge in the unforeseeable future to impact the directions of African tourism currently tourism and change research is overwhelmingly dominated by the pandemic's impact and responses. The review material serves to highlight an emerging African scholarship which is engaging on a range of issues around the themes of ramification, adaptation and transformation. Given the poverty challenges of the African continent, it is argued that policy-related issues around tourism and change are inevitably dominant on the agenda of African-based scholars. Overall, the COVID-19 crisis stresses the urgency of developing better change management practices and for building resilience, most especially for nature-based tourism destinations and protected areas across sub-Saharan Africa (Giddy and Rogerson, 2021; Spenceley et al., 2021; Stone et al., 2021).

\section{Acknowledgements}

Thanks go to Arabella Rogerson for editorial assistance and to Robbie, Dawn and Skye Norfolk for their inputs.

\section{REFERENCES}

Acquaah, M., Nanatovu, R., \& Kiggundu, M.N. (2021). Preliminary investigations into the COVID-19 pandemic and management in Africa. Africa Journal of Management, 7 (1), 1-12. https://doi.org/10.1080/23322373.2021.1882223

Adinolfi, M., Harilal, V., \& Giddy, J.K. (2021). Travel stokvels, leisure on lay by, and pay at your pace options: The post COVID-19 domestic tourism landscape in South Africa. African Journal of Hospitality, Tourism and Leisure, 10 (1), $302-317$. https://doi.org/10.46222/ajhtl.19770720-102 
Adu-Ampong, E., \& Kimbu, A. (eds.) (2021). Sustainable tourism policy and planning in Africa. Abingdon: Routledge.

Adu-Ampong, E., \& Mensah, C. (2021). Tourism and hospitality research in the peripheries: Thematic focus and a research agenda for Ghana. African Journal of Hospitality, Tourism and Leisure, 10 (3), 302-317. https://doi.org/10.46222/ajhtl.19770720-151

Aidoo, S.O., Agyapong, A., Acquaah, M., \& Akomea, S.Y. (2021). The performance implications of startegic responses of SMEs to the covid-19 pandemic: Evidence from an African economy. Africa Journal of Management, 7 (1), 74-103. https://doi.org/10.1080/23322373.2021.1878810

Alhammad, F.A. (2020). Trends in tourism entrepreneurship; A systematic review. Jordan Journal of Business Administration, 16 (1), $307-330$.

Arezki, R., Djankov, S., \& Panizza, U. (2021). Shaping Africa's post-Covid recovery. (eds.), London: Centre for Economic Policy Research Press.

Arezki, R., Froidevaux, A., Huynh, T.L., Nguyen, H.M., \& Salez, N. (2021). The state of tourism in Africa during Covid-19 and beyond; Evidence from big data. In R. Arezki, S. Djankov \& U. Panizza (eds), Shaping Africa's post-Covid recovery, 85-96, London: Centre for Economic Policy Research Press.

Assaf, A., \& Scuderi, R. (2020). COVID-19 and the recovery of the tourism industry. Tourism Economics, 26 (5), $731-733$. https://doi.org/10.1177\%2F1354816620933712

Assaf, A.G., Kock, F., \& Tsionas, M. (2021). Tourism during and after COVID-19: An expert-informed agenda for tourism research. Journal of Travel Research. https://doi.org/10.1177/00472875211017237

Ayiine-Etigo, D.A., \& Amankwah-Amoah, J. (2021). COVID-19 and Africa's aviation and tourism sectors: A new agenda for the future? Tourism Management Perspectives, 39, 100840. https://doi.org/10.1016/j.tmp.2021.100840

Bama, H.K.N., \& Nyikana, S. (2021). The effects of COVID-19 on future domestic travel intentions in South Africa: A stakeholder perspective. African Journal of Hospitality, Tourism and Leisure, 10 (1), 179-193. https://doi.org/10.46222/ajhtl.19770720-94

Bianchi, R.V. (2020). COVID-19 and the potential for a radical transformation of tourism? ATLAS Tourism and Leisure Review 2020-2, 80-86.

Booyens, I., Rogerson, C.M., Rogerson, J.M., \& Baum, T. (2021). COVID-19 crisis management responses by small tourism firms in South Africa. Tourism Review International, 25 (3-4).

Brouder, P. (2020). Reset redux: Possible evolutionary pathways towards the transformation of tourism in a COVID-19 world. Tourism Geographies, 22 (3), 484-490. https://doi.org/10.1080/14616688.2020.1760928

Buckley, R. (2020). Nature tourism and mental health: Parks, happiness, and causation. Journal of Sustainable Tourism, 28 (9), 14091424. https://doi.org/10.1080/09669582.2020.1742725

Buheji, M., da Costa Cunha, K., Beka, G., Mavrić, B., de Souza, Y.L., da Costa Silva, S.S., Hanafi, M., \& Yein, T.C. (2020). The extent of COVID-19 pandemic socio-economic impact on global poverty: A global integrative multidisciplinary review. American Economic Review, 10 (4), 213-224. https://doi.org/10.5923/j.economics.20201004.02

Butler, G., Szili, G., Cutler, C., Hay, I., \& Saikia, U. (2021). Changing Australian leisure mobilities in the COVID-19 pandemic: Exploring the role of automobilities. Leisure Studies. https://doi.org/10.1080/02614367.2021.1916833

Butler, R. (2020). Tourism - resilient but vulnerable as "the times they are a changing in the "new normality". Worldwide Hospitality and Tourism Themes, 12 (6), 663-670. https://doi.org/10.1108/WHATT-07-2020-0063

Chebli, A., \& Said, F.B. (2020). The impact of COVID-19 on tourist consumption behaviour: A perspective article. Journal of Tourism Management Research, 7 (2), 196-207.

Chen, S.H., Huang, J., \& Tham, A. (2021). A systematic literature review of coffee and tea tourism. International Journal of Culture, Tourism and Hospitality Research, 15 (3), 290-311. https://doi.org/10.1108/IJCTHR-08-2020-0173

Chipumuro, J., Mihailescu, R., \& Rinaldi, A. (2021). Gener disparities in employability in the tourism sector post-COVID-19 pandemic: Case of South Africa. In V.G. Gowreesunkar, S.W. Maingi, H. Roy \& R. Micera (eds.), Tourism destination management in a postpandemic context, 173-184, Bingley: Emerald

Chirisa, I., Mavhima, B., Nyevera, T., Chigudu, A., Makochekanwa, A., Matai, J., Masunda, T., Chandaengerwa, E.K., Machingura, F., Moyo, S., Chirisa, H., Mhloyi, M., Murwira, A., Mhandara, L., Katsande, R., Muchena, K., Manjeya, E., Nyika, T., \& Mundau, L. (2021). The impact and implications of COVID-19: Reflections on the Zimbabwean society. Social Sciences \& Humanities Open, 4, 100183. https://doi.org/10.1016/j.ssaho.2021.100183

Chirisa, I., Mutambisi, T., Chivenge, M., Mbasera, M., Sidambe, M., Muchenje, B., Mukwashi, T., Mabaso, E., Ncube, R., \& Zengeni, D. (2020). Scope for virtual tourism in the times of COVID-19 in select African destinations. Journal of Social Science, 64 (1-3), 113. https://doi.org/10.31901/24566756.2020/64.1-3.2266

Cooper, M.A., \& Buckley, R. (2021). Tourist mental health drives destination choice, marketing, and matching. Journal of Travel Research. https://doi.org/10.1177/00472875211011548

Dayour, F., Adongo, C.A., Amuquandoh, F.E., \& Adam, I. (2020). Managing the COVID-19 crisis: Coping and post-recovery strategies for hospitality and tourism businesses in Ghana. Journal of Hospitality and Tourism Insights. https://doi.org/10.1108/JHTI-08-2020-0150

Drummond, F.J. (2021). The role of tourism in small town cultural and creative industries clustering: The Sarah Baartman District, South Africa. In C.M. Rogerson \& J.M. Rogerson (eds.), Urban tourism in the Global South: South African perspectives, 213-237, Cham, Switzerland: Springer.

Duarte Alonso, A., Kok, S.K., Bressan, A., O’Shea, M., Sakellarios, N., Koresis, A., Solis, M.A.B., \& Santoni, L.J. (2020). COVID-19, aftermath, impacts, and hospitality firms: An international perspective. International Journal of Hospitality Management, 91, 1026554. https://doi.org/10.1016/j.ijhm.2020.102654

Dube, K. (2021a). Implications of COVID-19 induced lockdown on the South African tourism industry and prospects for recovery. African Journal of Hospitality, Tourism and Leisure, 10 (1), 270-287. https://doi.org/10.46222/ajhtl.19770720-99

Dube, K. (2021b). Sustainable Development Goals localisation in the hospitality sector in Botswana and Zimbabwe. Sustainability, 13, 8457. https://doi.org/10.3390/su13158457

Dube-Xaba, Z. (2021). COVID-19 lockdown and visiting friends and relatives travellers: Impacts and opportunities. African Journal of Hospitality, Tourism and Leisure, 10 (3), 856-862. https://doi.org/10.46222/ajhtl.19770720-136

Fitchett, J.M. (2021). Climate change threats to urban tourism in South Africa. In C.M. Rogerson \& J.M. Rogerson (eds.), Urban tourism in the Global South: South African perspectives, 77-91, Cham, Switzerland: Springer.

Garrido-Moreno, A., Garcia-Morales, V.J., \& Martin-Rojas, R. (2021). Going beyond the curve: Strategic measures to recover hotel activity in times of COVID-19. International Journal of Hospitality Management, 96, 102928. https://doi.org/10.1016/j.ijhm.2021.102928

Giddy, J.K., \& Rogerson, J.M. (2021). Nature-based tourism enterprise adaptive responses to COVID-19 in South Africa. GeoJournal of Tourism and Geosites, 36 (2 Supplement), 698-707. https://doi.org/10.30892/gtg.362spl18-700 
Gössling, S., Scott, D., \& Hall, C.M. (2021). Pandemics, tourism and global change: A rapid assessment of COVID-19. Journal of Sustainable Tourism, 29 (1), 1-20. https://doi.org/10.1080/09669582.2020.1758708

Gursoy, D., \& Chi, C.G. (2020). Effects of COVID-19 pandemic on hospitality industry: Review of the current situation and research agenda. Journal of Hospitality Marketing \& Management, 29 (5), 527-529. https://doi.org/10.1080/19368623.2020.1788231

Hall, C.M., Scott, D., \& Gössling, S. (2020). Pandemics, transformations and tourism: Be careful what you wish for. Tourism Geographies, 22 (3), 577-598. https://doi.org/10.1080/14616688.2020.1759131

Hambira, W.L., Stone, L.S., \& Pagiwa, V. (2021). Botswana nature-based tourism and COVID-19: Transformational implications for the future. Development Southern Africa. https://doi.org/10.1080/0376835X.2021.1955661

Higgins-Desbiolles, F. (2020a). COVID-19 and tourism: Reclaiming tourism as a social force? ATLAS Tourism and Leisure Review, 2020-2, 65-73.

Higgins-Desbiolles, F. (2020b). Socialising tourism for social and ecological justice after COVID-19. Tourism Geographies, 22 (3), 610620. https://doi.org/10.1080/14616688.2020.1757748

Kock, F., Nǿrfelt, A., Josiassen, A., Assaf, A.G., \& Tsionas, M.G. (2020). Understanding the COVID-19 psyche: The evolutionary tourism paradigm. Annals of Tourism Research, 85, 103053. https://doi.org/10.1016/j.annals.2020.103053

Kwok, A.O.J., \& Koh, S.G.M. (2021). Lux in tenebris: Content analysis of Covid-19 research. In P. Jose, M. Sigala, P. Whitelaw \& I. Ye (eds.), Transformations in uncertain times: Future perfect in tourism, hospitality and events: Proceedings of the $31^{\text {st }}$ Annual Conference, Council for Australasian University Tourism and Hospitality Education (CAUTHE), 386-391, Adelaide: CAUTHE.

Leonard, L., Musavengane, R., \& Siakweh, P. (Eds.) (2021). Sustainable urban tourism in sub-Saharan Africa. Abingdon: Routledge.

Lewis, F., Browne, M. \& Houdet, J. (2021). COVID-19 - What is the impact for tourism as a vehicle of SMME development and incentivizing environmental management in South Africa. African Journal of Hospitality, Tourism and Leisure, 10 (3), $987-998$. https://doi.org/10.46222/ajhtl.19770720-144

Makoni, L., \& Tichaawa, T.M. (2021). Impact analysis of the COVID-19 pandemic on the informal sector business tourism economy of Zimbabwe. African Journal of Hospitality, Tourism and Leisure, 10 (1), 165-178. https://doi.org/10.46222/ajhtl.19770720-93

Masaki, E.A., John, W.F., \& Abel, C. (2021). Impact of ICT tools and apps on tourism destination marketing: A case of RDB and Marriot Hotels, Kigali, Rwanda. International Journal of Social Science and Economic Research, 6 (4), $1232-1249$. https://doi.org/10.46609/IJSSER.2021.v06i04.008

Matiza, T., \& Slabbert, E. (2021). Tourism is too dangerous!: Perceived risk and the subjective safety of tourism activity in the era of COVID-19. GeoJournal of Tourism and Geosites, 36 (2 Supplement), 580-588. https://doi.org/10.30892/gtg.362spl04-686

Mattei, A., Chiritâ, V., \& Lupchian, M.M. (2021). Governance and tourism resilience building during the COVID19 crisis: Case study Bukovina, Romania. GeoJournal of Tourism and Geosites, 34 (1), 256-262. https://doi.org/10.30892/gtg.34135-646

Mensah, E.A., \& Boakye, K.A. (2021). Conceptualizing post-COVID-19 tourism recovery: A three-step framework. Tourism Planning \& Development. https://doi.org/10.1080/21568316.2021.1945674

Mohamed, T.A.P. (2021). Covid-19 pandemic peak period: Challenges and overcoming measures followed in the star-rated hotels in Gondar town, Ethiopia. European Online Journal of Natural and Social Sciences, 10 (1), 85-92.

Muragu, M.M., Nyadera, I.N., \&, Mbugua, C.W. (2021). Gearing up for the new normal: Kenya's tourism sector before and after the COVID-19 pandemic. Journal of Policy Research in Tourism, Leisure and Events. https://doi.org/10.1080/19407963.2021.1903020

Musango, H.J., \& Rusibana, C. (2021). The effect of information and communication to revenue collection in selected hotels in Kigali. International Journal of Advanced Scientific Research and Management, 6 (3), 32-43. https://doi.org/10.36282/IJASRM/6.3.2021.1799

Musavengane, R., Leonard, L., \& Mureyani, S. (2020). Doing tourism in Southern Africa amid the coronavirus pandemic: Navigating political, socio-economic and environmental inequalities. Development Southern Africa. https://doi.org/10.1080/0376835X.2020.1829459

Mwamwaja, E.E., \& Mlozi, S. (2020). An assessment of the impact of COVID-19 pandemic in the tourism sector in Tanzania. International Tourism and Hospitality Journal, 3 (4), 1-15. https://doi.org/10.37227/ITHJ-2020-02-56

Nair, B.B., \& Mohanty, P.P. (2021). Positioning spice tourism as an emerging form of special interest tourism: Perspectives and strategies. Journal of Ethnic Foods, 8, 10. https://doi.org/10.1186/s42779-021-00086-4

Nair, B.B., \& Sinha, S. (2020). COVID-19 and future travel decisions: How do destination-choice-based motivators redefine tourist's choices. Enlightening Tourism: A Pathmaking Journal, 10 (2), 306-322.

Ngoasong, M.Z., Adeola, O., Kimbu, A.N., \& Hinson, R.E. (eds.), (2021). New frontiers in hospitality and tourism management in Africa. Cham, Switzerland: Springer Nature.

Nhamo, G., Dube, K., \& Chikodzi, D. (2020). Counting the cost of COVID-19 on the global tourism industry. Cham, Switzerland: Springer Nature.

Niewiadomski, P. (2020). COVID-19: From temporary de-globalisation to a rediscovery of tourism? Tourism Geographies, 22 (3), 651656. https://doi.org/10.1080/14616688.2020.1757749

Novelli, M., Adu-Ampong, E., \& Ribeiro, M. (eds.). (2021). Routledge handbook of tourism in Africa. Abingdon: Routledge.

Nunkoo, R., Smith, S.L.J., \& Ramkissoon, H. (2013). Residents' attitudes to tourism: A longitudinal study of 140 articles from 1984 to 2010. Journal of Sustainable Tourism, 21 (1), 5-25.

Nyaruwata, S., \& Mbasera, M. (2021). A critique of contribution of tourism to jobs in Southern African Development Community (SADC): Implications for post COVID-19 pandemic. International Tourism and Hospitality Journal, 4 (5), 1-18. https://doi.org/10.37227/ITHJ-2021-03-116

Nyawo, J.C. (2020). Evaluation of government responses and measures on COVID-19 in the tourism sector: A case of tour guides in South Africa. African Journal of Hospitality, Tourism and Leisure, 9 (5), 1144-1160. https://doi.org/10.46222/ajhtl.19770720-74

Ozili, P. (2020). COVID-19 in Africa: Socio-economic impact, policy response and opportunities. International Journal of Sociology and Social Policy. https://doi.org/10.1108/IJSSP-05-2020-0171

Pandy, W., \& Rogerson, C.M. (2021). Climate change risks and tourism in South Africa: Projections and policy. GeoJournal of Tourism and Geosites, 35 (2), 445-455. https://doi.org/10.30892/gtg.35224-671

Persson-Fischer, U., \& Liu, S. (2021). The impact of a global crisis on areas and topics of tourism research. Sustainability, 13 (2), 906. https://doi.org/10.3390/su13020906

Pham, T.D., Dwyer, L., Su, J.J., \& Ngo, T. (2021). COVID-19 impacts of inbound tourism on the Australian economy. Annals of Tourism Research, 88, 103179. https://doi.org/10.1016/j.annals.2021.103179

Pillai, S.G., Haldorai, K., Seo, W.S., \& Kim, W.G. (2021). COVID-19 and hospitality 5.0: Redefining hospitality operations. International Journal of Hospitality Management, 94, 102869. https://doi.org/10.1016/j.ijhm.2021.102869

Rastegar, R., Higgins-Desboilles, F., \& Ruhanen, L. (2021). COVID-19 and a justice framework to guide tourism recovery. Annals of Tourism Research ahead of print. https://doi.org/10.1016/j.annals.2021.103161 
Rogerson, C.M. (2012). The tourism-development nexus in sub-Saharan Africa: Progress and prospects. Africa Insight, 42 (2), $28-45$.

Rogerson, C.M., \& Baum, T. (2020). COVID-19 and African tourism research agendas. Development Southern Africa, 37 (5), $727-741$. https://doi.org/10.1080/0376835X.2020.1818551

Rogerson, C.M., \& Rogerson, J.M. (2020a). COVID-19 tourism impacts in South Africa: Government and industry responses. GeoJournal of Tourism and Geosites, 31 (3), 1083-1091. https://doi.org/10.30892/gtg.31321-544

Rogerson, C.M., \& Rogerson, J.M. (2020b). COVID-19 and tourism spaces of vulnerability in South Africa. African Journal of Hospitality, Tourism and Leisure, 9 (4), 382-401. https://doi.org/10.46222/ajhtl.19770720-26

Rogerson, C.M., \& Rogerson, J.M. (2021a). COVID-19 travel intentions and changing consumer demand: Research review and policy implications for South Africa. African Journal of Hospitality, Tourism and Leisure, 10 (1), 1-21. https://doi.org/10.46222/ajhtl.19770720-83

Rogerson, C.M., \& Rogerson, J.M. (eds.), (2021b). Urban tourism in the Global South: South African perspectives. Cham, Switzerland: Springer.

Rogerson, C.M., \& Rogerson, J.M. (2021c). Looking to the past: The geography of tourism in the pre-COVID-19 era. In C.M. Rogerson \& J.M. Rogerson (eds.), Urban tourism in the Global South: South African perspectives, 39-75, Cham, Switzerland: Springer.

Rogerson, C.M., \& Rogerson, J.M. (2021d). Creative networks and the making of Africa's first UNESCO creative city of gastronomy. In C.M. Rogerson \& J.M. Rogerson (eds.), Urban tourism in the Global South: South African perspectives, 239-266, Cham, Switzerland: Springer.

Rogerson, C.M., \& Rogerson, J.M. (2021e). Niche tourism research and policy: International and South African debates. African Journal of Hospitality, Tourism and Leisure, 10 (4).

Rogerson, C.M., \& Rogerson, J.M. (2021f). Climate therapy and the development of South Africa as a health resort, c1850-1910. Bulletin of Geography: Socio-Economic Series, 52, 111-121.

Rogerson, J.M. (2021). Tourism business responses to South Africa's COVID-19 state of emergency. GeoJournal of Tourism and Geosites, 35 (2), 338-347. https://doi.org/10.30892/gtg.35211-657

Rogerson, J.M., \& Visser, G. (Eds.) (2020). New directions in South African tourism geographies. Cham, Switzerland: Springer.

Rogerson, J.M., Lekgau, R.J., Mashapa, M.M., \& Rogerson, C.M. (2021). Covid-19 and local business responses: Evidence from South Africa's most tourism-dependent locality. African Journal of Hospitality, Tourism and Leisure, 10 (1), 388-405. https://doi.org/10.46222/ajhtl.19770720-107

Saarinen, J. (2021). Tourism for change: Change management toward sustainable tourism development. In J. Saarinen \& J.M. Rogerson (eds.), Tourism, change and the Global South, 15-32, Abingdon: Routledge.

Saarinen, J., \& Rogerson, J.M. (2021). Tourism and change: Issues and challenges in the Global South. In J. Saarinen \& J.M. Rogerson (eds.), Tourism, change and the Global South, 3-14 Abingdon: Routledge.

Saarinen, J., \& Wall-Reinius, S. (Eds.) (2021). Tourism enclaves: Geographies of exclusive spaces in tourism. Abingdon: Routledge.

Sao Joao, E. (2021). COVID-19 and hospitality operations: What happened and what's next. African Journal of Hospitality, Tourism and Leisure, 10 (1), 318-332.

Senbeto, D.L., Koseoglu, M.A., \& King, B. (2021). Hospitality and tourism scholarship in Africa: A literature-based agenda for future research. Journal of Hospitality \& Tourism Research. https://doi.org/10.1177/10963480211011540

Sharma, G.D., Thomas, A., \& Paul, J. (2021). Reviving tourism industry post-COVID-19. Tourism Management Perspectives, 37, 100786. https://doi.org/10.1016/j.tmp.2020.100786

Sibanda, T., \& Cheer, J. (2021). Impacts of tourism on the livelihoods of women in Victoria Falls, Zimbabwe. In J. Saarinen \& J.M. Rogerson (eds.), Tourism, change and the Global South, 169-186, Abingdon: Routledge.

Sigala, M. (2020). Tourism and COVID-19: Impacts and implications for advancing and resetting industry and research. Journal of Business Research, 117,312-321. https://doi.org/10.1016/j.jbusres.2020.06.015

Sin, H.L., Mostafanezhad, M., \& Cheer, J.M. (2021). Tourism geographies in the 'Asian Century'. Tourism Geographies, 23 (4), 649658. https://doi.org/10.1080/14616688.2020.1826571

Soliku, O., Kyiire, B., Mahama, A., \& Kunio, C. (2021). Tourism and COVID-19 pandemic: Impacts and implications for building resilience in the eco-tourism sector in Ghana's Savannah region. Heliyon, 7, e07892. https://doi.org/10.1016/j.heliyon.2021.e07892

Spenceley, A., McCool, S., Newsome, D., Baez, A., Barborak, J.R., Blye, C-J., Bricker, K., Cahyadi, H.S., Corrigan, K., Halpenny, E., Hvenegaard, G., King, D.M., Leung, Y.F., Mandic, A., Naidoo, R., Ruede, D., Sano, J., Sarhan, M., Santamaria, V., Sousa, T.B., \& Zschiegner, A.K. (2021). Tourism in protected and conserved areas amid the COVID-19 pandemic. Parks, 27 (Special), $103-113$. https://doi.org/10.2305/IUCN.CH.2021.PARKS-27-SIAS.en

Stone, L.S., Stone, M.T., Mogomotsi, P.K., \& Mogomotsi, G.E.J. (2021). The impacts of Covid-19 on nature-based tourism in Botswana: Implications for community development. Tourism Review International, 25 (2-3), 263-278. https://doi.org/10.3727/154427221 X16098837279958

Sucheran, R. (2021). Preliminary economic impacts of the COVID-19 pandemic on the hotel sector in South Africa. African Journal of Hospitality, Tourism and Leisure, 10 (1), 115-130. https://doi.org/10.46222/ajhtl.19770720-90

Swart, K., \& Maralack, D. (2021). COVID-19 and the cancellation of the 2020 Two Oceans Marathon, Cape Town, South Africa. Sport in Society, 23 (11), 1736-1752. http://dx.doi.org/10.1080/17430437.2020.1805900

Tellioglu, S. (2021). The impact of COVID-19 on the supply chains of all-inclusive hotels. GeoJournal of Tourism and Geosites, 35 (2), 464-470. https://doi.10.30892/gtg35226-673

Trip, D.T., Fagadar, C.F., Badulescu, D., \& Badulescu, A. (2021). Entrepreneurship and tourism through the lens of sustainability: Charting the knowledge base through bibliometric analysis. GeoJournal of Tourism and Geosites, 34 (1), $140-146$. https://doi.10.30892/gtg34118-629

Woyo, E. (2021). The sustainability of using domestic tourism as a post-COVID-19 recovery strategy in a distressed destination. In W. Wörndl, C. Koo, \& J.L. Stienmetz (Eds.), Information and communication technologies in tourism 2021, 476-489. Cham, Switzerland: Springer.

Woyo, E., \& Nyamandi, C. (2021). Application of virtual reality technologies in the comrades' marathon as a response to COVID-19 pandemic. Development Southern Africa. https://doi.org/10.1080/0376835X.2021.1911788

Zenker, S., \& Kock, F. (2020). The coronavirus pandemic - A critical discussion of a tourism research agenda. Tourism Management, 81, 104164. https://doi.org/10.1016/j.tourman.2020.104164

*** OECD (2020). COVID-19 and Africa: Socio-economic implications and policy responses. Paris: OECD Policy Responses to Coronavirus.

*** UNDP (2021). Maximising tourism's contribution to Africa's COVID-19 recovery. 21 June 2021. https://www.undp.org/pressleases/maximising-tourism-contribution-africas-covid-19-recovery 